\author{
KAROLINA STOPKA \\ ORCID: 0000-0003-1199-9350 \\ Uniwersytet Wrocławski \\ Instytut Prawa Cywilnego \\ Zakład Prawa Pracy
}

\title{
O REALIZACJI ZABEZPIECZENIA SPOŁECZNEGO W PRZEPISACH KODEKSU PRACY
}

\begin{abstract}
Abstrakt: Opracowanie jest głosem w dyskusji na temat uprawnień pracownika unormowanych w kodeksie pracy stanowiących wyjątek od ściśle rozumianej zasady wzajemności i ekwiwalentności świadczeń ze stosunku pracy. Uprawnienia te poddano analizie z perspektywy zabezpieczenia społecznego, w tym ochrony socjalnej przysługującej pracownikowi w ramach ubezpieczenia społecznego, formułując wnioski co do zasadności utrzymania ich w kodeksie pracy lub właściwego ich ukształtowania.
\end{abstract}

Słowa kluczowe: zabezpieczenie społeczne, prawo pracy, ryzyko socjalne, zabezpieczenie dochodu

\section{WPROWADZENIE}

Prawo pracy dotyczy stosunków pracy — ekwiwalentnej wymiany pracy na wynagrodzenie. Praca nie jest jednak jedyną racją i miarą wszystkich uprawnień pracownika, w tym mających przymiot wynagrodzenia. Uwaga ta dotyczy zwłaszcza uprawnień przysługujących pracownikowi w razie wystąpienia przeszkód w realizacji obowiązków pracowniczych. W nauce prawa pracy uprawnienia te uzasadnia się zagrożeniami, jakie generuje każdy proces pracy dla życia i zdrowia pracownika, w tym dla jego życia rodzinnego, oraz korzyściami, jakie towarzyszą zatrudnianiu pracowników - przyczynianiem się pracownika do realizacji celów pracodawcy poprzez oddawaną siłę roboczą ${ }^{1}$. Wskazuje się też, że regulacja prawna tych uprawnień jest wyrazem zakorzenionej społecznie potrzeby sprawowania przez pracodawców opieki nad pracownikiem, który nie jest w stanie wykonywać

${ }^{1}$ Szerzej np. Ł. Pisarczyk, Wynagrodzenie czy zasitek - w sprawie świadczeń za czas niezdolności do pracy, [w:] Wynagrodzenie za pracę w warunkach społecznej gospodarki rynkowej $i$ demokracji, red. W. Sanetra, Warszawa 2009, s. 178-179, 191; D. Dzienisiuk, Prawo pracy a prawo ubezpieczeń społecznych, Warszawa 2016, s. 65. 
pracy $^{2}$. Łączy się ją również z potrzebą ochrony pracownika przed hegemoniczną pozycją pracodawcy ${ }^{3}$ czy też rzadziej — przed dysfunkcjonalnością praw wolnego rynku ${ }^{4}$, a ostatnio poddano ją analizie z perspektywy polityki społecznej oraz społecznych praw socjalnych człowieka pracującego ${ }^{5}$. Można jednak przyjąć, że uprawnienia pracownicze, $\mathrm{w}$ tym mające postać określonych świadczeń pieniężnych, służą realizacji zabezpieczenia społecznego i w konsekwencji rozpatrywać ich zasadność czy też właściwy kształt z tej właśnie perspektywy.

Zabezpieczenie społeczne jest pojęciem interdyscyplinarnym, a jego zasadniczym elementem jest zabezpieczenie dochodu. W nauce prawa zabezpieczenia społecznego pojęcie to łączy się na ogół z systemem świadczeń o charakterze ubezpieczeniowym i zaopatrzeniowym służących zaspokajaniu potrzeb jednostki i rodziny wynikłych z ryzykownych zdarzeń, stanowiących przejaw realizacji przez państwo prawa do zabezpieczenia społecznego zadeklarowanego w art. 67 Konstytucji, w aktach międzynarodowych i unijnych ${ }^{6}$. Zakres przedmiotowy tak rozumianego prawa do zabezpieczenia społecznego obejmuje przede wszystkim ochronę na wypadek niezdolności do pracy z powodu choroby, inwalidztwa, wypadku przy pracy i choroby zawodowej, osiągnięcia wieku emerytalnego, macierzyństwa, utraty żywiciela rodziny oraz bezrobocia. Tak rozumiane prawo do zabezpieczenia społecznego może być realizowane nie tylko poprzez instrumenty oparte na różnych wariantach solidarności zbiorowej, których przejawem są wspomniane świadczenia o charakterze ubezpieczeniowym i zaopatrzeniowym (solidarność ubezpieczeniowa, solidarność społeczna), ale również przez instrumenty oparte na solidarności indywidualnej — obciążeniach pracodawcy ${ }^{7}$.

Akty statuujące prawo do zabezpieczenia społecznego pozostawiają ustawodawcy zwykłemu swobodę wyboru form realizacji zabezpieczenia społecznego. Tylko niektóre akty prawnomiędzynarodowe ograniczają tę swobodę. Czynią to jednak albo poprzez przypisanie konkretnej formie priorytetowego znaczenia w re-

2 D. Dzienisiuk, op. cit., s. 236, 315.

3 Tak np. A. Świątkowski, M. Wujczyk, Bezpieczeństwo prawne i socjalne jako uniwersalna aksjologiczna podstawa współczesnego prawa pracy i zabezpieczenia społecznego. Wybrane zagadnienia, [w:] Aksjologiczne podstawy prawa pracy i ubezpieczeń społecznych, red. M. Skąpski, K. Ślebzak, Poznań 2014, s. 167.

4 Tak np. A. Sobczyk, Prawo i czlowiek pracujący - między ochrona godności a równości, [w:] Aksjologiczne podstawy prawa pracy i ubezpieczeń społecznych, red. M. Skąpski, K. Ślebzak, Poznań 2014, s. 35-36, 39.

5 Zob. M. Mędrala, Społeczny charakter świadczeń w polskim prawie pracy, Warszawa 2019.

${ }^{6}$ Zwłaszcza konwencji $\mathrm{nr} 102 \mathrm{MOP}$ dotyczącej minimalnych norm zabezpieczenia społecznego, stanowiącej aktualnie najważniejszy akt prawny i podstawowy instrument międzynarodowy w dziedzinie zabezpieczenia społecznego. Szerzej: K. Ślebzak, Prawo do zabezpieczenia społecznego w Konstytucji RP. Zagadnienia podstawowe, Warszawa 2016, s. 41-62.

7 A. Sobczyk, Prawo pracy w świetle Konstytucji RP, t. 2. Wybrane problemy i instytucje prawa pracy a konstytucyjne prawa i wolności człowieka, Warszawa 2013, s. 179. Zob. także D. Dzienisiuk, op. cit., s. 314. 
alizacji zabezpieczenia społecznego ${ }^{8}$, albo wyłącznie w odniesieniu do ochrony konkretnego ryzyka ${ }^{9}$. Warto również dodać, że u początku umiędzynarodowienia praw socjalnych zdarzenia takie jak choroba, choroby zawodowe, nieszczęśliwe wypadki spowodowane pracą miały podlegać ochronie w ramach instrumentów prawa pracy. Konstytucja MOP nie wspominała w ich przypadku o powołaniu jakieś formy zaopatrzenia celem ich ochrony ${ }^{10}$. Uzasadniając temat rozważań, warto wskazać również na obowiązek pracodawcy dbania o zabezpieczenie społeczne pracowników wyprowadzony przez TK z solidarności stanowiącej, w ujęciu Konstytucji $\mathrm{RP}^{11}$, jeden $\mathrm{z}$ fundamentów społecznej gospodarki wolnorynkowej $\left(\right.$ art. 20) ${ }^{12}$. W istocie zatem od decyzji politycznej prawodawcy zależy, czy pracownik w związku z zaistnieniem określonego ryzyka uzyska świadczenie na podstawie prawa pracy lub prawa zabezpieczenia społecznego, czy też na podstawie obu tych systemów ${ }^{13}$. Biorąc pod uwagę, że realizacja prawa do zabezpieczenia społecznego zakłada podejmowanie działań nie tylko mających na celu wprowadzenie konkretnych świadczeń (przysporzeń finansowych), ale również ułatwianie i promowanie zabezpieczenia społecznego ${ }^{14}$, instrumenty k.p. realizujące zabezpieczenie społeczne z założenia nie muszą mieć jednorodnego charakteru, w tym — zwłaszcza — finansowej postaci.

Stosownie do przyjętego rozumienia prawa do zabezpieczenia społecznego oraz środków jego realizacji tematu opracowania dotyczą przepisy: a) art. 92 k.p.

${ }^{8}$ Zob. art. 2 zalecenia nr 67 MOP dotyczącego zabezpieczenia dochodu, wedle którego zabezpieczenie dochodów powinno w możliwie największym stopniu opierać się na obowiązkowym ubezpieczeniu społecznym.

${ }^{9}$ Uwaga ta dotyczy ochrony niemożności świadczenia pracy z powodu macierzyństwa. W odniesieniu do tego ryzyka akty międzynarodowe proklamują potrzebę zapewnienia pracującym kobietom w okresie okołoporodowym ochrony w postaci świadczeń z obowiązkowego ubezpieczenia społecznego lub funduszy publicznych (zob. art. 3 konwencji nr 3 MOP dotyczącej zatrudnienia kobiet przed i po porodzie, art. 4 konwencji MOP nr 103 z dnia 4 czerwca 1952 roku dotyczącej ochrony macierzyństwa (Dz.U. z 1976 r. Nr 16, poz. 99) oraz art. 6 nieratyfikowanej przez Polskę konwencji MOP Nr 183 z dnia 15 czerwca 2000 roku dotyczącej ochrony macierzyństwa, rewidującej konwencję nr 103; art. 8 Europejskiej Karty Społecznej z 1961 roku (Dz.U. z 1999 r. Nr 8, poz. 67), wyjątkowo w formie płatnego urlopu lub urlopu z zapewnieniem odpowiednich zasiłków (zob. art. 10 ust. 2 Międzynarodowego Paktu Praw Gospodarczych, Społecznych i Kulturalnych z dnia 19 grudnia 1966 roku (Dz.U. z 1977 r. Nr 38, poz. 169); art. 33 ust. 2 Karty Praw Podstawowych UE (Dz.Urz. UE 2016/C 202) oraz art. 8 Dyrektywy Rady 92/85/EWG z dnia 19 października 1992 roku w sprawie wprowadzenia środków służących wspieraniu poprawy w miejscu pracy bezpieczeństwa i zdrowia pracownic w ciąży, pracownica, które niedawno rodziły, i pracownic karmiących piersią. Dyrektywa przewiduje również, że pracownica w ciąży, której udzielono urlopu z powodu braku możliwości zapewnienia jej odpowiednich w świetle dyrektywy warunków pracy, może w tym okresie korzystać z praw pracowniczych związanych z umową o pracę, obejmujących utrzymanie płatności na jej podstawie, i/lub prawa do odpowiednich zasiłków — art. 11 ust. 1.

10 K. Roszewska, Ryzyko niezdolności do pracy, Warszawa 2018, s. 114.

11 Ustawa z dnia 2 kwietnia 1997 roku, Dz.U. z 1997 r. Nr 78, poz. 483 ze zm.

12 Wyrok TK z dnia 30 stycznia 2001 roku, K 17/00, OTK ZU 2001, Nr 1, poz. 4.

13 D. Dzienisiuk, op. cit., s. 55, 59.

${ }^{14}$ Szerzej K. Ślebzak, op. cit., s. 42-43. 
statuujące prawo do wynagrodzenia chorobowego nawiązujące do ryzyka czasowej niezdolności do pracy; b) art. $92^{1}$ k.p. statuujące prawo do odprawy emerytalnej (rentowej) nawiązujące do ryzyka dożycia wieku emerytalnego i ryzyka niezdolności do pracy; c) art. 93 normujące prawo do odprawy pośmiertnej nawiązujące do ryzyka śmierci żywiciela rodziny; d) art. 179 i $178^{1}$ in fine k.p. przewidujące obowiązek zwolnienia ciężarnej pracownicy lub karmiącej dziecko piersią ze świadczenia dotychczasowej pracy przy zachowaniu prawa do nieumniejszonego wynagrodzenia za pracę lub „zmiany dotychczasowych warunków świadczenia pracy" z zachowaniem prawa do dodatku wyrównawczego nawiązujące do ryzyka niemożności świadczenia pracy z powodu macierzyństwa; e) art. 230 i 231 k.p. przewidujące prawo do dodatku wyrównawczego do wynagrodzenia dla pracownika przeniesionego do innej pracy w związku ze stwierdzeniem objawów wskazujących na powstawanie choroby zawodowej, lub który stał się niezdolny do wykonywania dotychczasowej pracy wskutek wypadku przy pracy, lub choroby zawodowej i nie został uznany za niezdolnego do pracy w rozumieniu ustawy o emeryturach i rentach z Funduszu Ubezpieczeń Społecznych ${ }^{15}$ nawiązujące do ryzyka wypadków przy pracy i chorób zawodowych; f) działu 8 k.p. pod tytułem „Uprawnienia pracowników związane z rodzicielstwem” statuujące prawo do urlopu macierzyńskiego, urlopu macierzyńskiego, urlopu ojcowskiego oraz urlopu na warunkach urlopu macierzyńskiego nawiązujące do ryzyka niemożności świadczenia pracy z powodu macierzyństwa; g) art. $92 \S 4$, art. 184 i art. $237^{1}$ k.p. wskazujące na prawo pracownika do określonych świadczeń ubezpieczenia społecznego.

Wymienione w punktach od a) do e) instrumenty zapewniają ochronę pierwotną i z tego względu uznać można je za wyraz realizacji prawa do zabezpieczenia społecznego w ujęciu ścisłym. Instrumenty wymienione w punkcie f) pełnią funkcję wspierająco-wykonawczą i jako takie stanowią wyraz ochrony prawa do zabezpieczenia społecznego rozumianej jako zagwarantowanie dostępności zabezpieczenia społecznego, czyli możliwości faktycznego korzystania ze świadczeń zabezpieczenia społecznego unormowanych poza prawem pracy. Natomiast regulacje wskazane w punkcie g) pełnią funkcję natury informacyjnej.

Dalsze rozważania skupiać się będą wokół instrumentów pierwszej grupy, a więc tych, które należą się za „niepracę" ${ }^{16}$ (brak świadczenia jakiejkolwiek pracy) lub „niepracę umówioną" (świadczenie pracy na innych warunkach niż umówiona) i stanowią wyjątek od ściśle rozumianej zasady wzajemności i ekwiwalentności świadczeń ze stosunku pracy ${ }^{17}$, bez uwzględnienia jednak wynagrodzenia chorobowego. Za pominięciem rozważań na temat wynagrodzenia chorobowego przemawiają ograniczone ramy opracowania a także to, że regulacja prawna wy-

15 Tekst jedn. Dz.U. z 2018 r. poz. 1270 ze zm., dalej: ustawa emerytalna.

16 Określeniem „niepraca” posługiwał się np. J. Jończyk, Ryzyko pracodawcy związane z choroba, [w:] Ubezpieczenia chorobowe, red. B. Wagner, A. Malaka, Iwonicz-Zdrój 2010, s. 8 n.

17 Ibidem, s. 7. 
nagrodzenia chorobowego była przedmiotem licznych wypowiedzi doktryny, które zachowują swą aktualność także w obranej perspektywie badawczej ${ }^{18}$.

Zasadniczo cechą wspólną badanych instytucji jest to, że nie uwzględniają one zróżnicowanej struktury i sytuacji rynkowej pracodawców, w tym ich wielkości i kondycji finansowej oraz zróżnicowanych podstaw zatrudnienia pracowniczego i jego przebiegu. Zaistnienie sytuacji chronionej i warunków nabycia prawa nakłada na pracodawcę każdorazowo obowiązek ich realizacji. Za wyjątkiem wynagrodzenia chorobowego świadczenia te są niezależne od świadczeń z systemu zabezpieczenia społecznego i nie wpływają na ich realizację, co nie oznacza, że przepisy ubezpieczeniowe nie kształtują treści uprawnienia do nich (odprawa pośmiertna).

\section{INSTYTUCJE K.P. REALIZUJĄCE ZABEZPIECZENIE SPOŁECZNE - RYS HISTORYCZNY}

Obciążanie pracodawców kosztami nieświadczenia przez pracownika umówionej pracy nie jest wytworem k.p. Jeszcze przed jego uchwaleniem pracodawcy, w rożnych formach i w różnym zakresie, zobowiązani byli do świadczeń na rzecz pracowników niemogących świadczyć umówionej pracy lub członków ich rodzin w razie ich śmierci ${ }^{19}$.

Spośród instrumentów objętych analizą w tekście pierwotnym k.p. przewidziana była tylko odprawa pośmiertna oraz dodatki wyrównawcze dla pracowników, którym zmieniono dotychczasowe warunki pracy ze względu na ciążę ${ }^{20}$, stwierdzenie choroby zawodowej ${ }^{21}$, lub którzy stali się niezdolni do wykonywania dotychczasowej pracy wskutek wypadku przy pracy lub choroby zawodowej i nie zostali uznani za niezdolnych do pracy w rozumieniu obowiązujących wówczas przepisów emerytalno-rentowych ${ }^{22}$. Regulację prawną odprawy emerytalnej i rentowej wpro-

18 Zob. np. B. Wagner, Zasitki i wynagrodzenie za czas nieobecności w pracy, PUSiG 2000, nr 5, s. 5; eadem, Wprowadzenie, [w:] Ubezpieczenia chorobowe..., s. 5-6; Ł. Pisarczyk, op. cit., s. 237-257, 287; A. Napiórkowska, Wynagrodzenie za pracę $w$ okresie niezdolności do pracy z powodu choroby, [w:] Wynagrodzenie za prace w warunkach..., s. 214-215; J. Jończyk, op. cit., s. 7, 9-12.

19 Tak w odniesieniu do ryzyka skutków choroby pracownika H. Pławucka, Świadczenia pieniężne w związu z choroba, [w:] Ubezpieczenie chorobowe, red. J. Jończyk, Wrocław 1984, s. 52. Zob. np. art. 19, 20, 42 rozporządzenia Prezydenta Rzeczypospolitej z dnia 16 marca 1928 roku o umowie o pracę pracowników umysłowych, Dz.U. z 1928 r. Nr 35, poz. 323; art. 42 rozporządzenia Prezydenta Rzeczypospolitej z dnia 16 marca 1928 roku o umowie o pracę robotników, Dz.U. z 1928 r. Nr 35, poz. 324; art. 95 ust. 4, 5 ustawy z dnia 28 marca 1933 roku o ubezpieczeniu społecznym, Dz.U. z 1933 r. Nr 51, poz. 396; art. 8 ustawy z dnia 6 czerwca 1958 roku o zwalczaniu nadużyć w zakresie wykorzystywania zaświadczeń o czasowej niezdolności do pracy, Dz.U. z 1958 r. Nr 35, poz. 154.

20 Zob. art. 179 k.p. w brzmieniu pierwotnym.

21 Zob. art. 217 § 3 k.p. w brzmieniu pierwotnym.

22 Zob. art. 218 k.p. w brzmieniu pierwotnym. 
wadziła zaś do k.p. obszerna prorynkowa nowelizacja z 1996 roku $^{23}$. Do tego czasu odprawy emerytalne i rentowe nie miały charakteru powszechnego, przewidywały je wyłącznie pragmatyki służbowe lub zakładowe przepisy płacowe i w konsekwencji wypłacali je tylko ci pracodawcy, u których obowiązywały pozytywne normy płacowe $\mathrm{w}$ tym zakresie ${ }^{24}$. Aktualny zakres podmiotowy i przedmiotowy ochrony dla pracownic ciężarnych i karmiących dziecko piersią zapoczątkowała natomiast nowelizacja k.p. z 2001 roku $^{25}$.

Z ogólnej perspektywy można przyjąć, że analizowane w opracowaniu instrumenty stanowią częściowo wyraz dostosowania prawa pracy do przemian społeczno-gospodarczych w Polsce po 1989 roku, których następstwem było stopniowe przekształcanie struktury własnościowej podmiotów gospodarczych, oparcie ich działalności na zasadach gospodarki wolnorynkowej oraz pojawienie się nowych zjawisk na rynku pracy związanych między innymi z racjonalizacją zatrudnienia skutkującą masowym bezrobociem ${ }^{26}$. Na tym tle, w szerszej perspektywie, nałożenie na pracodawcę obowiązków w zakresie zabezpieczenia dochodów pracownika i jego rodziny - poprzez nadanie uprzednio występującym świadczeniom powszechnego charakteru lub wprowadzenie nowych świadczeń — uznać można za sposób uzyskania społecznej akceptacji dla dokonujących się przemian czy też przeciwwagę dla proefektywnościowych przekształceń w funkcjonowaniu przedsiębiorstw charakteryzujących się podejmowaniem działań bazujących na opłacalności i zysku, w zgodzie z zasadą społecznej gospodarki rynkowej. Wprawdzie od strony formalnoprawnej zasada społecznej gospodarki rynkowej może uchodzić za podstawę zmian w k.p. od chwili wejścia w życie Konstytucji RP z 2 kwietnia 1997 roku, jednak już w exposé premiera T. Mazowieckiego, wygłoszonym 24 sierpnia 1989 roku, pojęciem tym posłużono się na określenie pożądanego modelu ustroju społeczno-gospodarczego ${ }^{27}$.

Dla dalszych rozważań istotne jest również podkreślenie, że badane instrumenty wprowadzono do porządku prawnego $\mathrm{w}$ istocie przed reformą ubezpieczeń społecznych z końca lat dziewięćdziesiątych XX wieku oraz przed przekształ-

${ }^{23}$ L. Florek, Wynagrodzenie za pracę w gospodarce rynkowej, [w:] Z aktualnych zagadnień prawa pracy $i$ zabezpieczenia społecznego. Ksiega Jubileuszowa Profesora Waleriana Sanetry, red. B. Cudowski, J. Iwulski, s. 108; ustawa z dnia 2 lutego 1996 roku o zmanie ustawy — Kodeks pracy oraz o zmianie niektórych ustaw, Dz.U. z 1996 r. Nr 24, poz. 110.

${ }^{24}$ Szerzej zob. M. Rafacz-Krzyżanowska, Odprawa emerytalna i rentowa, PiZS 1996, nr 3, s. $49-55$.

25 Ustawa z dnia 24 sierpnia 2001 roku o zmianie ustawy - Kodeks pracy oraz zmianie innych niektórych ustaw, Dz.U. z 2001 r. Nr 128, poz. 1405 zmieniająca k.p., co do zasady, z dniem 1 stycznia 2002 roku.

26 Zob. Z. Salwa, Przeksztatcenie systemu polskiego prawa pracy, [w:] Lad społeczny w Polsce i Niemczech na tle jednoczacej się Europy. Księga pamiatkowa poświęcona Czesławowi Jackowiakowi, red. B. von Maydell, T. Zieliński, Warszawa 1999, s. 125-133.

27 M. Skąpski, Realizacja idei społecznej gospodarki rynkowej w polskim ustroju pracy, „Ruch Prawniczy, Ekonomiczny i Socjologiczny” 2014, nr 2, s. 109. 
ceniami, które dokonały się na rynku pracy, wywierając wpływ na ich aktualny stan prawny, wśród których wskazać wypada między innymi zróżnicowanie form prowadzenia działalności zarobkowej, rosnącą mobilność pracowników czy destabilizację stosunków pracy oraz wzrost zatrudnienia na podstawie umów cywilnoprawnych. Wszystko to rodzi pytanie, czy wyrażający się w tych instrumentach obowiązek pracodawcy zabezpieczenia bytu pracownika i jego rodziny jest obecnie faktycznie niezbędny i właściwie ukształtowany, zwłaszcza w wypadku pracodawców działających $\mathrm{w}$ sektorze prywatnym. Instrumenty służące realizacji tego obowiązku przez pracodawców sektora publicznego przewidują przepisy szczególne. Ich ocena jest jednak sprawą o wiele bardziej złożoną, wymagającą odrębnych rozważań. Instrumenty te są bowiem finansowane ze środków publicznych pokrywających koszty ich działalności i z tego względu trudno uznać je za przejaw solidarności indywidualnej w czystej postaci. Nadto przy ocenie tych instrumentów wypada mieć na względzie szczególne właściwości zatrudnienia u pracodawców sektora publicznego związane z udziałem pracowników w realizacji zadań państwa w szeroko rozumianej sferze publicznej czy też ograniczoną swobodą pracodawcy kształtowania warunków płacowych.

\section{ODPRAWA EMERYTALNA (RENTOWA)}

Odprawa emerytalna (rentowa) przysługuje pracownikowi spełniającemu warunki uprawniające do renty z tytułu niezdolności do pracy lub emerytury, którego stosunek pracy ustał w związku z przejściem na rentę lub emeryturę. Świadczenie to zapewnia ochronę na niskim poziomie. Odprawa przysługuje w wysokości jednomiesięcznego wynagrodzenia, a pracownik, który otrzymał odprawę, nie może ponownie nabyć do niej prawa.

W piśmiennictwie i judykaturze wskazuje się, że odprawa emerytalna (rentowa) jest świadczeniem socjalnym związanym z zakończeniem aktywności zawodowej, które ma ułatwić pracownikowi przystosowanie się do nowych warunków życiowych ${ }^{28}$, złagodzić skutki materialne i moralne zmiany statusu osoby czynnej zawodowo, która staje się z dnia na dzień beneficjentem świadczeń długoterminowych z ubezpieczenia społecznego ${ }^{29}$. Socjalny walor tego świadczenia podkreśla niewątpliwie brak jakichkolwiek przesłanek warunkujących uprawnienie do niego związanych z przebiegiem zatrudnienia pracownika. Świadczenie to jest niezależne od stażu pracy, tak ogólnego, jak i zakładowego, rodzaju zawartej umowy o pracę

28 R. Sadlik, Odprawa przy odchodzeniu na emeryturę lub rentę, „Służba Pracownicza” 2010, nr 4, s. 23. Por. też uchwalę SN z dnia 31 maja 1989 roku, III PZP 52/88, OSNCP 1989, nr 12, poz. 190.

${ }^{29}$ H. Pławucka, Prawo do odprawy emerytalnej osoby pobierającej świadczenie emerytalne w trakcie zatrudnienia, „Nowe Zeszyty Samorządowe” 2001, nr 4, s. 80 i przywołana tam literatura. 
czy też jakości pracy świadczonej na rzecz pracodawcy ${ }^{30}$. Socjalny charakter tego świadczenia potwierdza również powszechne dziś zjawisko mobilności pracowników i pozostawianie przez nich w okresie aktywności zarobkowej w stosunkach pracy z wieloma pracodawcami, a nie — jak przed laty — wieloletnie zatrudnienie $\mathrm{u}$ jednego pracodawcy. Dlatego też w aktualnym stanie prawnym i społeczno-rynkowym trudno ujmować odprawę emerytalną (rentową) w kategoriach gratyfikacji pieniężnej z tytułu wysługi lat pracy ${ }^{31}$ czy też swoistego zadośćuczynienia pieniężnego ${ }^{32}$.

Choć między przyznaniem prawa do emerytury lub renty a ustaniem stosunku pracy musi istnieć związek funkcjonalny, przyczynowy czy też czasowy, to przyznanie prawa do emerytury lub renty i faktyczne ich pobieranie może nastąpić po pewnym czasie od ustania stosunku pracy. Dlatego też można przyjąć, że obciążenie pracodawcy odprawą emerytalną ustanowione jest ze względu na zabezpieczającą funkcję wynagrodzenia za pracę, które stanowi dla pracownika źródło utrzymania i ma na celu zabezpieczenie bytu pracownika i jego rodziny ${ }^{33} \mathrm{~W}$ okresie zmiany jego statusu z pracownika na status emeryta lub rencisty poprzez złagodzenie następstw ewentualnej luki w zapewnieniu podstaw egzystencji w tym okresie. Właściwość tę analizowane świadczenie nabrało zwłaszcza po 1 stycznia 1999 roku wraz z utratą mocy przepisów ustawy z dnia 14 grudnia 1982 roku o zaopatrzeniu emerytalnym pracowników i ich rodzin ${ }^{34}$ i ograniczeniem przez obowiązującą ustawę emerytalną treści obowiązków pracodawcy w dochodzeniu przez pracowników uprawnień emerytalno-rentowych, w szczególności poprzez uwarunkowanie przedłożenia organowi rentowemu wniosku o emeryturę lub rentę od zgody pracownika, ujednolicenie i skrócenie okresu, w jakim wniosek ten powinien wpłynąć do organu rentowego, oraz eliminację obowiązku pracodawcy przedłużenia stosunku pracy do dnia wydania decyzji w razie niemożności jej wydania przez organ rentowy lub dokonania wypłaty świadczenia w kwocie zaliczkowej od dnia, w którym ustałby stosunek pracy z przyczyn leżących po stronie pracodawcy ${ }^{35}$. Zmiana treści obowiązków pracodawcy w tym zakresie niewątpliwie osłabiła możliwość realizacji uprawnień emerytalno-rentowych wraz z rozwiązaniem stosunku pracy. Wysokość odprawy wskazuje jednak, że jest to bardziej symboliczny niż faktyczny instrument stabilizacji pozycji jednostki w społeczeństwie ${ }^{36}$. Poza tym

${ }^{30}$ Zob. S. Kryczka, Wynagrodzenie za prace - wybrane problemy, „Służba Pracownicza” 2014, nr 5, s. 12.

31 Na taki charakter odprawy wskazywała np. H. Pławucka, Prawo do odprawy emerytalnej..., s. 80 .

32 J. Strusińska-Żukowska, Odprawy pieniężne dla pracowników, „Prawo Pracy” 2000, nr 1, s. 10 .

33 Zob. W. Szubert, Zarys prawa pracy, Warszawa 1972, s. 224.

34 Dz.U. Nr 40, poz. 267 ze zm.

35 Zob. art. 96-97 ustawy o zaopatrzeniu emerytalnym pracowników i ich rodzin oraz art. 125 ustawy emerytalnej.

36 Por. Ł. Pisarczyk, op. cit., s. 236. 
wydaje się, że w aktualnych warunkach rynkowych wzgląd na przeciwdziałanie wykluczeniu z rynku pracy osób w wieku przedemerytalnym przemawia za zwolnieniem pracodawcy z obowiązku wypłaty tego świadczenia, przynajmniej w jego aktualnym kształcie, nieuwarunkowanym stażem zakładowym. Poza tym skoro odprawa ta zwiększa koszty pracy, jej eliminacja lub ponownie uczynienie autonomicznych źródeł prawa pracy źródłem prawa podmiotowego uzasadniającego żądanie jej wypłaty mogłoby wpłynąć pozytywnie na promowanie wśród podmiotów zatrudniających zatrudnienia pracowniczego i stanowić pośredni instrument walki z tak zwanymi umowami śmieciowymi czy też zjawiskiem nieformalnego zatrudnienia. Dodatkowo za zwolnieniem pracodawców z obowiązku wypłaty odprawy emerytalnej czy też rentowej przemawia ich wkład w finansowanie ubezpieczenia społecznego. Składki, które opłacają pracodawcy na ubezpieczenia społeczne, stanowiąc przejaw współodpowiedzialności pracodawcy za wyczerpywanie w procesie pracy sił fizycznych i psychicznych pracownika ${ }^{37}$, zabezpieczają nie pracodawcę, lecz pracownika przed skutkami ryzyka dożycia wieku emerytalnego lub niezdolności do pracy. Wyjątkowy charakter w tym zakresie ma składka opłacana przez pracodawcę na ubezpieczenie wypadkowe. Służy ona nie tylko zaspokojeniu potrzeb pracownika, który uległ wypadkowi przy pracy lub zachorował na chorobę zawodową, ale również spełnia funkcję składki na ubezpieczenie tegoż pracodawcy od odpowiedzialności cywilnej w tym sensie, że gdyby nie to ubezpieczenie, to odpowiedzialność cywilna pracodawcy z tytułu wypadku przy pracy lub choroby zawodowej pracownika byłaby szersza ${ }^{38}$. W tym kontekście za zasadny uznać można byłoby obowiązek wypłaty odprawy pracownikowi, który stał się niezdolny do pracy z powodu wypadku przy pracy lub choroby zawodowej.

\section{ODPRAWA POŚMIERTNA}

Zgodnie z art. 93 k.p. w razie śmierci pracownika w czasie trwania stosunku pracy lub w czasie pobierania po jego rozwiązaniu zasiłku z tytułu niezdolności do pracy wskutek choroby rodzinie przysługuje od pracodawcy odprawa pośmiertna (§ 1). Odprawa przysługuje: małżonkowi i innym członkom rodziny spełniającym warunki wymagane do uzyskania renty rodzinnej w myśl przepisów ustawy emerytalnej (§ 4) w wysokości uzależnionej od okresu zatrudnienia pracownika u danego pracodawcy $(\S 2)$ i liczby uprawnionych członków rodziny ( $5-6)$. Odprawa pośmiertna nie przysługuje, jeżeli pracodawca ubezpieczył pracownika na życie, a odszkodowanie wypłacone przez instytucję ubezpieczeniową jest nie

37 D.E. Lach, Podzial skladki na ubezpieczenia społeczne zatrudnionych a rola podmiotu zatrudniającego, [w:] Składki na ubezpieczenie społeczne, red. K. Ślebzak, Warszawa-Poznań 2015, s. 63 .

38 W. Sanetra, O genezie i ewolucji sktadki na ubezpieczenie społeczne, [w:] Sktadki na ubezpieczenie społeczne, red. K. Ślebzak, Warszawa-Poznań 2015, s. 11; D.E. Lach, op. cit., s. 57-58. 
niższe niż odprawa pośmiertna przysługująca według wyżej wymienionych przepisów k.p. (§ 7).

W nauce prawa pracy przyjmuje się, że odprawa pośmiertna jest świadczeniem szczególnym na rzecz rodziny zmarłego pracownika z tytułu jego długoletniej pracy ${ }^{39}$ czy też swoistym zadośćuczynieniem pieniężnym wypłacanym członkom rodziny pracownika ${ }^{40}$. Wskazuje się również, że jest świadczeniem niezależnym od świadczeń ubezpieczeniowych (takich jak zasiłki pogrzebowe czy renty rodzinne) przysługujących rodzinie pracownika na odrębnych zasadach ${ }^{41}$, w ramach ubezpieczenia rentowego, a w przypadku śmierci będącej następstwem wypadku przy pracy lub choroby zawodowej — w ramach ubezpieczenia wypadkowego. Tym, co łączy jednak oba typy świadczeń, jest śmierć żywiciela rodziny.

Z perspektywy obowiązującej regulacji można przyjąć, że obciążenie pracodawcy odprawą pośmiertną ustanowione jest, podobnie jak w przypadku odprawy emerytalnej (rentowej), ze względu na zabezpieczającą funkcję wynagrodzenia za pracę, które, jak już wskazywano, stanowi źródło utrzymania nie tylko pracownika, ale również członków jego rodziny, a dodatkowo także ze względu na wkład zmarłego pracownika w rozwój zakładu pracy, skoro wysokość odprawy jest uzależniona od okresu zatrudnienia pracownika u danego pracodawcy. Taki charakter odprawy pośmiertnej ma również swoje uzasadnienie w zasadach ustalania i wypłaty świadczeń ubezpieczeniowych, które nie gwarantują rodzinie zmarłego pracownika ciągłości źródeł utrzymania. Pracodawca nie jest płatnikiem renty rodzinnej ani zasiłku pogrzebowego — w niektórych przypadkach co najwyżej ciąży na nim obowiązek poinformowania bezzwłocznie po śmierci pracownika pozostałej po nim rodziny o warunkach uzyskania renty rodzinnej, przygotowania wniosku o rentę i przedłożenia go organowi rentowemu ${ }^{42}$. Organ rentowy nie ma zaś obowiązku wypłacenia tych świadczeń w terminie przyjętym dla wypłaty wynagrodzenia zmarłego pracownika, lecz w ciągu 30 dni po stwierdzeniu uprawnień, co powinno z kolei nastąpić w ciągu 30 dni od wyjaśnienia ostatniej okoliczności niezbędnej do wydania decyzji ${ }^{43}$. De facto rentę rodzinną można uzyskać po kilku miesiącach od śmierci pracownika.

Obciążenie pracodawców obowiązkiem wypłaty odprawy pośmiertnej można natomiast uznać za wątpliwe w kontekście aktualnego wkładu pracodawcy w finansowanie świadczeń z ubezpieczenia społecznego, zwłaszcza z ubezpieczenia rentowego. Począwszy od dnia 1 lipca 2007 roku, na pracodawcy spoczywa zasadniczy ciężar finansowania składek na ubezpieczenie rentowe $\mathrm{w}$ związku $z$ rezygnacją przez ustawodawcę $z$ dotychczasowej zasady finansowania składki rentowej w częściach równych przez pracodawcę (płatnika składek) i pracowni-

\footnotetext{
39 W. Szubert, op. cit., s. 224.

40 J. Strusińska-Żukowska, op. cit., s. 10.

41 W. Szubert, op. cit., s. 224.

42 Zob. art. 125 ustawy emerytalnej.

43 Zob. art. 118 i 120 ustawy emerytalnej.
} 
ka (ubezpieczonego) ${ }^{44}$, przy czym od 1 lutego 2012 roku pracodawca finansuje składkę na ubezpieczenie rentowe w wysokości $6,5 \%$ podstawy wymiaru z $8 \%$ podstawy jej wymiaru ${ }^{45}$, co oznacza, że opłaca ponad $80 \%$ składki rentowej. Skoro składka ma na celu otrzymanie czy też zapewnienie prawa do określonego świadczenia z ubezpieczenia społecznego ${ }^{46}$, a składka opłacana przez pracodawcę jest jednocześnie świadczeniem na rzecz pracownika ${ }^{47}$ niemającym w przypadku ubezpieczenia rentowego bezpośredniego związku z procesem pracy ${ }^{48} \mathrm{i}$ z tego względu stanowiącym tylko odpłatę za prawo korzystania z pracy świadczonej przez pracownika ${ }^{49}$ - jego sił fizycznych i psychicznych — to można zaryzykować twierdzenie, że jej finansowanie przez pracodawcę powinno zwalniać go z obowiązku wypłaty świadczeń chroniących sytuacje zabezpieczane przez świadczenia $\mathrm{z}$ ubezpieczenia rentowego lub opłacania składki na ubezpieczenie na życie pracownika celem zwolnienia się z tego obowiązku lub złagodzenia jego dolegliwości. Z przyczyn podanych w punkcie trzecim rację bytu ma natomiast ewentualnie obowiązkowa odprawa pośmiertna dla członków rodziny pracownika zmarłego wskutek wypadku przy pracy lub choroby zawodowej.

\section{4. ŚWIADCZENIA ZWIĄZANE Z TAK ZWANYMI PRZENIESIENIAMI OCHRONNYMI LUB ZWOLNIENIEM Z OBOWIĄZKU ŚWIADCZENIA PRACY}

Zdolność pracownika samozabezpieczenia środków egzystencji obniża również macierzyństwo ${ }^{50}$, rozumiane na potrzeby opracowania jako stosunek istniejący między dzieckiem i jego matką od początku ciąży ${ }^{51}$, oraz choroby zawodowe i wypadki przy pracy. Przed brakiem lub zmniejszeniem środków utrzymania w tych przypadkach zabezpieczają pracownika tak zwane przeniesienia ochronne do innej odpowiedniej pracy, z którymi łączy się prawo do dodatku wyrównaw-

${ }^{44}$ M. Bartoszewska, Komentarz do art. 16, [w:] Ustawa o systemie ubezpieczeń społecznych. Komentarz, red. J. Wantoch-Rekowski, LEX 2015.

45 Zmiana wprowadzona ustawą z dnia 21 grudnia 2011 roku o zmianie ustawy o systemie ubezpieczeń społecznych, Dz.U. z 2011 r. Nr 291, poz. 1706.

46 D. Dzienisiuk, op. cit., s. 178.

47 K. Ślebzak, Prawny charakter składek na ubezpieczenie spoteczne, [w:] Ubezpieczenie społeczne - dawniej i dziś. W 80-lecie uchwalenia ustawy o ubezpieczeniu społecznym, Wrocław 2013, s. 107.

48 Zob. D.E. Lach, op. cit., s. 67.

49 Zob. K. Ślebzak, Prawny charakter sktadek..., s. 107.

${ }^{50}$ K. Roszewska, op. cit., s. 53.

51 W. Borysiak, [w:] Konstytucja RP, t. 1. Komentarz do art. 1-86, red. M. Safjan, L. Bosek, Warszawa 2016, s. 490. W doktrynie prawa rodzinnego uznaje się, że macierzyństwo powinno być odnoszone przede wszystkim do więzi łączącej kobietę ciężarną z jej nienarodzonym jeszcze dzieckiem (zob. J. Ignatowicz, M. Nazar, Prawo rodzinne, Warszawa 2005, s. 48). 
czego finansowanego przez pracodawcę lub zwolnienie z obowiązku świadczenia pracy z zachowaniem prawa do wynagrodzenia za pracę, gdy nie ma możliwości przeniesienia do innej pracy, wskazane bliżej w punkcie pierwszym opracowania.

W nauce przyjmuje się, że obciążenie pracodawcy konsekwencjami zmian w organizacji procesu pracy i ryzykiem płacowym ze względu na ochronę życia i zdrowia kobiety oraz dziecka stanowi przejaw zaangażowania podmiotu zatrudniającego $\mathrm{w}$ realizację istotnych celów społecznych ${ }^{52}$. Ze względu na minimalny standard tej ochrony wynikający z aktów prawnomiędzynarodowych i wspólnotowych oraz aktualny stan prawny ochrony macierzyństwa w ramach ubezpieczenia chorobowego uznać wypada instrument unormowany w art. 179 k.p., $178^{1}$ in fine k.p. za niezbędny. Bez finansowego udziału pracodawcy ochrona życia i zdrowia pracownicy oraz jej dziecka w okresie zmniejszonej przydatności do umówionej pracy z powodu ciąży lub karmienia nie byłaby prawnie zagwarantowana. De lege ferenda rozwiązaniem alternatywnym mogłoby być objęcie ryzyka niemożności świadczenia umówionej pracy z powodu ciąży/karmienia piersią systemem świadczeń z ubezpieczenia chorobowego, a dokładniej — zasiłkiem wyrównawczym. Za takim rozwiązaniem przemawia kilka argumentów. Po pierwsze, przyczyna nieświadczenia umówionej pracy pozostaje w tym przypadku w pełni poza zakresem oddziaływania pracodawcy. W piśmiennictwie wskazuje się zaś, że brak wpływu pracodawcy na przyczyny nieświadczenia pracy powinien być brany pod uwagę przy politycznym wyborze metod zaspokajania potrzeb i sposobu ich finansowania $^{53}$. Po drugie, zasiłek wyrównawczy, mając obecnie na celu wyrównanie pracownikowi redukcji zarobków spowodowanej obniżeniem sprawności do pracy oraz koniecznością poddania się rehabilitacji zawodowej (por. art. 23 ustawy zasiłkowej), jest świadczeniem w praktyce zanikającym, od wielu lat niewykazywanym w obciążeniach statystycznych ZUS ${ }^{54}$. Wprowadzenie proponowanej zmiany prowadziłoby do zmiany charakteru zasiłku wyrównawczego jako świadczenia związanego z chorobą na świadczenie związane z macierzyństwem, adresowane do zdrowej ubezpieczonej pracownicy, która ze względu na macierzyństwo została odsunięta od wykonywania dotychczasowych czynności. W ujęciu tego świadczenia ciąża stanowiłaby źródło zmniejszonej sprawności do pracy umówionego rodzaju. Zmiana legislacyjna w tym zakresie mogłaby przemawiać na rzecz uznania zmniejszenia sprawności do pracy za samodzielne zdarzenie ubezpieczeniowe. Aktualnie zmniejszenie sprawności do pracy ma taki charakter tylko w ubezpie-

52 Ł. Pisarczyk, op. cit., s. 252, 257, 261.

53 Tak np. D. Dzienisiuk, op. cit., s. 62, 189.

54 T. Bińczycka-Majewska, Powszechność systemu ubezpieczeń społecznych - teoria i praktyka, [w:] Systemy ubezpieczeń społecznych - między solidaryzmem a indywidualizmem, Warszawa-Lublin 2014, s. 86. Zob. także M. Zieleniecki, Rola zasiłku wyrównawczego i renty szkoleniowej w rehabilitacji zawodowej, [w:] Ryzyko niezdolności do pracy w zabezpieczeniu społecznym, red. U. Jackowiak, R. Ziółkowska, Gdańsk 2006, s. 49. 
czeniu wypadkowym ${ }^{55}$. Proponowana zmiana w aspekcie systemowym nadałaby zasiłkowi wyrównawczemu jednorodny charakter - jako świadczenia pełniącego funkcję kompensacyjną. Jak dotychczas zasiłek wyrównawczy z ubezpieczenia chorobowego, w przeciwieństwie do zasiłku wyrównawczego z ubezpieczenia wypadkowego, z racji wymogu poddania się przez ubezpieczonego rehabilitacji zawodowej, poza funkcją kompensacyjną, pełni również funkcję prewencyjną ${ }^{56}$. Wreszcie, zwolnienie pracodawcy z wypłaty pracownicy wynagrodzenia za pracę lub dodatku wyrównawczego mogłoby szerzej zapobiegać dyskryminacji kobiet w wieku prokreacyjnym na rynku pracy.

Przewidziane natomiast w art. $230 \S 2$ i 231 k.p. prawo do dodatku wyrównawczego do wynagrodzenia dla pracownika przeniesionego do innej pracy, odpowiednio, w związku ze stwierdzeniem objawów wskazujących na powstawanie choroby zawodowej, lub który stał się niezdolny do wykonywania dotychczasowej pracy wskutek wypadku przy pracy lub choroby zawodowej i nie został uznany za niezdolnego do pracy w rozumieniu ustawy emerytalnej, ocenić wypada z perspektywy prawa do zasiłku wyrównawczego z ubezpieczenia wypadkowego. Unormowany w tych przepisach dodatek wyrównawczy z racji tego, że ma na celu wyrównanie redukcji zarobków pracownika przeniesionego do innej pracy w związku z wypadkiem przy pracy lub chorobą zawodową, odnosi się wprost do sytuacji objętej ochroną $\mathrm{w}$ ramach zasiłku wyrównawczego z ubezpieczenia wypadkowego. W świetle aktualnie obowiązujących przepisów zasiłek wyrównawczy ma na celu wyrównanie ubezpieczonemu pracownikowi redukcji zarobków spowodowanej obniżeniem sprawności do pracy wskutek stałego lub długotrwałego uszczerbku na zdrowiu doznanego w następstwie wypadku przy pracy lub choroby zawodowej ${ }^{57}$. W piśmiennictwie podkreśla się pokrewieństwo tych świadczeń ${ }^{58}$, jednocześnie odmiennie ocenia się ich wzajemne powiązania. Jedni autorzy akcentują samodzielny (niezależny) byt tych świadczeń ${ }^{59}$, jak się wydaje z uwagi na brak formalnoprawnych powiązań między nimi, inni wskazują zaś na ich zależność — przyjmując, że do okresu wypłaty zasiłku wyrównawczego wlicza się okresy pobierania dodatku wyrównawczego ${ }^{60}$. Zapatrywanie to czerpie z wykładni historycznej. Zasiłek wyrównawczy z ubezpieczenia wypadkowego zastąpił świadczenie wyrównawcze wypłacane przez pracodawcę pracownikowi, który wskutek wypadku przy pracy lub choroby zawodowej doznał stałego lub

55 Zob. M. Zieleniecki, op. cit., s. 38, 39 i przywołane tam poglądy piśmiennictwa. Odmienny stanowisko wynika z wyroku SN z dnia 18 lutego 2015 roku, I UK 243/14, OSNAPiUS 2016/11/142.

56 M. Zieleniecki, op. cit., s. 50.

57 Zob. art. 6 ust. 1 pkt. 3 ustawy wypadkowej.

58 M. Zieleniecki, op. cit., s. 38.

59 Tak np. J. Iwulski, [w:] Kodeks pracy. Komentarz, red. W. Sanetra, J. Iwulski, Warszawa 2013, s. 912.

60 A. Świątkowski, Kodeks pracy. Komentarz, Warszawa 2016, s. 1136; W. Ostaszewski, [w:] Spoleczne ubezpieczenia wypadkowe i chorobowe. Komentarz, red. M. Gersdorf, B. Gudowska, Warszawa 2012, s. 257. 
długotrwałego uszczerbku na zdrowiu w co najmniej $20 \%$ i osiągał wynagrodzenie zmniejszone co najmniej o $10 \%$ na podstawie przepisów ustawy z dnia 12 czerwca 1975 roku o świadczeniach z tytułu wypadków przy pracy i chorób zawodowych ${ }^{61}$ stanowiących między innymi o wliczaniu okresu pobierania dodatku wyrównawczego przewidzianego w art. 230 § 2 k.p. do trzyletniego okresu pobierania świadczenia wyrównawczego (art. 17 ust. 2).

Niewątpliwie obie kategorie świadczeń mają charakter kompensacyjny. Zasadnicza różnica między nimi dotyczy jednak przyczyn, dla których następuje redukcja zarobków ze względu na wypadek przy pracy lub chorobę zawodową. $\mathrm{W}$ przypadku dodatku, o którym mowa w art. $230 \S 2$ k.p., obniżenie sprawności do pracy wynika z samego stwierdzenia objawów choroby zawodowej u pracownika bez względu na jej następstwa dla stanu organizmu pracownika i zdolności do umówionej pracy. Przeniesienie ochronne ${ }^{62}$ ma tu charakter profilaktyczny zapobiega pogorszeniu stanu zdrowia pracownika skoro ma on wykonywać pracę nienarażającą go na działanie czynnika wywołującego te objawy. W przypadku dodatku wyrównawczego, o którym mowa w art. 231 § 1 in fine k.p., obniżenie sprawności do pracy wynika zaś z utraty zdolności do pracy dotychczasowej, nieskutkującej jednak niezdolnością do pracy w rozumieniu ustawy emerytalnej, i ma zapobiegać powstaniu tej niezdolności do pracy. Natomiast, jak już wskazano, zasiłek wyrównawczy kompensuje redukcję zarobków z powodu stałego i długotrwałego uszczerbku na zdrowiu będącego następstwem wypadku przy pracy lub choroby zawodowej. Odmienność rodzajowa skutków wypadków przy pracy i chorób zawodowych leżących u źródeł redukcji zarobków wskazuje, że świadczenia te nie są względem siebie w pełni konkurencyjne, co nie oznacza, że w konkretnym przypadku nie mogą nabrać takiego charakteru. Odmienność ta thumaczy brak regulacji prawnej wyłączającej prawo do zasiłku w razie pobierania dodatku czy też nakazującej wliczanie okresu pobierania dodatku do okresu zasiłkowego zasiłku wyrównawczego. Brak szczególnego przepisu w tym względzie uznać należy za przeszkodę zaliczania dodatków wyrównawczych na poczet zasiłku wyrównawczego. Przemawia za tym również odrębność stosunków prawnych uzasadniających żądanie ich wypłaty. Stwierdzenie to nie jest jednoznaczne z bezwzględną akceptacją dla aktualnego unormowania tych dodatków w k.p.

Fakt, że niezdolność do umówionej pracy lub niemożność wykonywania umówionej pracy wiąże się bezpośrednio z pracą, jak również to, że wypadki przy pracy czy choroby zawodowe w wielu przypadkach mają swe źródło w uchybieniach pracodawcy, uzasadnia generalnie obciążanie finansowe pracodawcy niemożnością wykonywania przez pracownika umówionej pracy ${ }^{63}$. Obciążenie składką na ubez-

61 Dz.U. Nr 20, poz. 105.

62 Określenie stosowane np. przez T. Wykę, [w:] Kodeks pracy. Komentarz, red. K.W. Baran, Warszawa 2018, komentarz do art. 230.

63 T. Bińczycka-Majewska, Charakterystyka i zakres świadczeń w systemie ubezpieczenia z tytułu wypadków przy pracy i chorób zawodowych, „Praca i Zabezpieczenie Społeczne” 2003, nr 5. 
pieczenie wypadkowe wyłącznie pracodawcy (przy uwzględnieniu zasad ustalania stopy procentowej składki uwzględniających tak zwany stopień wypadkowości ${ }^{64}$ oraz prawdopodobieństwo podwójnego kompensowania szkody polegającej na obniżonych zarobkach i tym samym wzbogacenia się pracownika ${ }^{65}$ ) może stanowić argument za potrzebą uchylenia tych regulacji. Uznanie istnienia potrzeby realizacji przez dodatki dodatkowej funkcji prewencyjnej w ramach stosunku pracy, przy zachowaniu ich aktualnego kształtu, przemawiałoby zaś za utrzymaniem ich niezależności mimo ewentualnego ryzyka podwójnej kompensacji ${ }^{66}$.

\section{ZAKOŃCZENIE}

Przeprowadzone rozważania wskazują na brak jednolitej, spójnej koncepcji ukształtowania świadczeń realizujących zabezpieczenie społeczne w k.p. W aktualnym kształcie trudno uznać je za faktyczny czy też niezbędny instrument wsparcia, stabilizacji pozycji pracownika (jego rodziny) w społeczeństwie uzasadniony zagrożeniami, które generuje proces świadczenia pracy, oraz korzyściami, jakie towarzyszą zatrudnianiu pracowników — skoro prawo do nich nie jest uwarunkowane minimalnym zakładowym stażem pracy.

Instrumenty zabezpieczające dochód pracownika w k.p. mają mocne uzasadnienie historyczne (moralne, obyczajowe i prawne). Względy czysto historyczne nie powinny jednak decydować o ich utrzymaniu.

W aktualnych warunkach prawnych, gospodarczych i społecznych w kodeksie pracy powinny dominować instrumenty ochronne — zabezpieczające sytuację ,„pracownika" (jego relacje rodzinne, zdrowie, życie) przed zagrożeniami, sytuacjami, które mogą na nią negatywnie wpłynąć (na przykład zakazy zwolnienia pracownika, zakazy zatrudniania kobiet w ciąży w godzinach nadliczbowych, w porze nocnej, w przerywanym czasie pracy, zakaz delegowania kobiety w ciąży bez jej zgody poza miejsce zamieszkania, elastyczne formy pracy ułatwiające łączenie pracy z funkcjami wynikającymi z macierzyństwa, rodzicielstwa itp.) oraz instrumenty pomocowe gwarantujące wsparcie w sytuacjach ograniczających lub wyłączających zdolność czy też możliwość świadczenia przez pracownika umówionej pracy, w tym łączących się z obowiązkiem pracodawcy zapewnienia im bezpiecznego środowiska pracy, nierodzące jednak dla pracodawcy, co do zasady, bezpośrednich ciężarów finansowych lub przynajmniej indywidualnie ponoszonego ciężaru finansowego (na przykład urlopy, przeniesienia ochronne, konieczność akceptacji przerw w procesie pracy uzasadnionych chociażby względami rodzinnymi lub społecznymi itp.).

${ }^{64}$ R. Garbiec, Finansowanie systemów ubezpieczeń społecznych na przykładzie Polski, Niemiec i Wielkiej Brytanii, „Nierówności Społeczne a Wzrost Gospodarczy” 2012, nr 24, s. 202.

65 W. Ostaszewski, op. cit., s. 257.

${ }^{66}$ Nieco inaczej propozycje rozwiązania tego problemu widzi T. Bińczycka-Majewska. Zob. eadem, op. cit., s. 20. 
Łagodziłoby to niepożądane praktyki selekcyjne w odniesieniu do osób szczególnie zagrożonych niezdolnością do pracy i niemożnością jej świadczenia, zwłaszcza osób w wieku przedemerytalnym, niepełnosprawnych czy też kobiet w wieku prokreacyjnym, których zatrudnianie zwiększa zakres ryzyka socjalnego pracodawcy. Struktura własnościowa pracodawców, udział w rynku pracy pracodawców sektora prywatnego, ich wielkość, procesy zachodzące na rynku pracy z jednej strony, z drugiej zaś ratio ubezpieczeń społecznych, zakres ochrony socjalnej pracownika, jego rodziny w ramach zorganizowanego przez państwo systemu świadczeń ubezpieczenia społecznego oraz udział pracodawcy w jego finansowaniu uzasadniają rewizję tej ochrony w obszarze k.p. poprzez jej zniesienie, a przynajmniej istotne ograniczenie (wynagrodzenie chorobowe), zniesienie i zastąpienie świadczeniami ubezpieczeniowymi (dodatki wyrównawcze, zwłaszcza przysługujące pracownicy ciężarnej lub karmiącej piersią) oraz przekształcenie w instrumenty, do których prawo wynika $\mathrm{z}$ autonomicznych źródeł prawa pracy (odprawa emerytalna, odprawa rentowa i odprawa pośmiertna), z wyjątkiem — ewentualnie — ochrony związanej $\mathrm{z}$ wypadkiem przy pracy lub chorobą zawodową.

\title{
ON THE IMPLEMENTATION OF SOCIAL SECURITY IN THE PROVISIONS OF THE LABOUR CODE
}

\begin{abstract}
Summary
The study is a voice in the discussion on employers' rights regulated in the Labour Code, which constitute an exception to the strictly understood principle of reciprocity and equivalence of employment benefits. These rights were analysed from the perspective of social security, including social protection due to the employee under social insurance. The study contains conclusions as to the legitimacy of maintaining them in the Labour Code or their proper regulation.
\end{abstract}

Keywords: social security, labour law, social risk, income security

\section{BIBLIOGRAFIA}

Bartoszewska M., Komentarz do art. 16, [w:] Ustawa o systemie ubezpieczeń społecznych. Komentarz, red. J. Wantoch-Rekowski, LEX 2015.

Bińczycka-Majewska T., Charakterystyka i zakres świadczeń w systemie ubezpieczenia z tytulu wypadków przy pracy i chorób zawodowych, „Praca i Zabezpieczenie Społeczne” 2003, nr 5.

Bińczycka-Majewska T., Powszechność systemu ubezpieczeń społecznych - teoria i praktyka, [w:] Systemy ubezpieczeń społecznych — między solidaryzmem a indywidualizmem, Warszawa-Lublin 2014.

Borysiak W., [w:] Konstytucja RP, t. 1. Komentarz do art. 1-86, red. M. Safjan, L. Bosek, Warszawa 2016.

Dzienisiuk D., Prawo pracy a prawo ubezpieczeń społecznych, Warszawa 2016. 
Florek L., Wynagrodzenie za prace w gospodarce rynkowej, [w:] Z aktualnych zagadnień prawa pracy $i$ zabezpieczenia społecznego. Księga Jubileuszowa Profesora Waleriana Sanetry, red. B. Cudowski, J. Iwulski, Warszawa 2013.

Garbiec R., Finansowanie systemów ubezpieczeń społecznych na przykładzie Polski, Niemiec i Wielkiej Brytanii, „Nierówności Społeczne a Wzrost Gospodarczy” 2012, nr 24.

Ignatowicz J., Nazar M., Prawo rodzinne, Warszawa 2005.

Iwulski J., [w:] Kodeks pracy. Komentarz, red. W. Sanetra, J. Iwulski, Warszawa 2013.

Jończyk J., Ryzyko pracodawcy związane z choroba, [w:] Ubezpieczenia chorobowe, red. B. Wagner, A. Malaka, Iwonicz-Zdrój 2010.

Kodeks pracy. Komentarz, red. K.W. Baran, Warszawa 2018.

Kodeks pracy. Komentarz, red. W. Sanetra, J. Iwulski, Warszawa 2013.

Konstytucja RP, t. 1. Komentarz do art. 1-86, red. M. Safjan, L. Bosek, Warszawa 2016.

Kryczka S., Wynagrodzenie za pracę - wybrane problemy, „Służba Pracownicza” 2014, nr 5.

Lach D.E., Podziat składki na ubezpieczenia społeczne zatrudnionych a rola podmiotu zatrudniajacego, [w:] Składki na ubezpieczenie społeczne, red. K. Ślebzak, Warszawa-Poznań 2015.

Mędrala M, Społeczny charakter świadczeń w polskim prawie pracy, Warszawa 2019.

Napiórkowska A., Wynagrodzenie za prace w okresie niezdolności do pracy z powodu choroby, [w:] Wynagrodzenie za pracę w warunkach społecznej gospodarki rynkowej i demokracji, red. W. Sanetra, Warszawa 2009.

Ostaszewski W., [w:] Społeczne ubezpieczenia wypadkowe i chorobowe. Komentarz, red. M. Gersdorf, B. Gudowska, Warszawa 2012.

Pisarczyk Ł., Wynagrodzenie czy zasitek - w sprawie świadczeń za czas niezdolności do pracy, [w:] Wynagrodzenie za pracę $w$ warunkach społecznej gospodarki rynkowej i demokracji, red. W. Sanetra, Warszawa 2009.

Pławucka H., Prawo do odprawy emerytalnej osoby pobierającej świadczenie emerytalne w trakcie zatrudnienia, ,Nowe Zeszyty Samorządowe” 2001, nr 4.

Pławucka H., Świadczenia pieniężne w związu z choroba, [w:] Ubezpieczenie chorobowe, red. J. Jończyk, Wrocław 1984.

Rafacz-Krzyżanowska M., Odprawa emerytalna i rentowa, PiZS 1996, nr 3.

Roszewska K., Ryzyko niezdolności do pracy, Warszawa 2018.

Sadlik R., Odprawa przy odchodzeniu na emeryturę lub rentę, „Służba Pracownicza” 2010, nr 4.

Salwa Z., Przekształcenie systemu polskiego prawa pracy, [w:] Lad społeczny w Polsce i Niemczech na tle jednoczacej się Europy. Księga pamiątkowa poświęcona Czesławowi Jackowiakowi, red. B. von Maydell, T. Zieliński, Warszawa 1999.

Sanetra W., O genezie i ewolucji składki na ubezpieczenie społeczne, [w:] Składki na ubezpieczenie społeczne, red. K. Ślebzak, Warszawa-Poznań 2015.

Skąpski M., Realizacja idei społecznej gospodarki rynkowej w polskim ustroju pracy, „Ruch Prawniczy, Ekonomiczny i Socjologiczny” 2014, nr 2.

Sobczyk A., Prawo i człowiek pracujący - między ochrona godności a równości, [w:] Aksjologiczne podstawy prawa pracy i ubezpieczeń społecznych, red. M. Skąpski, K. Ślebzak, Poznań 2014.

Sobczyk A., Prawo pracy w świetle Konstytucji RP, t. 2. Wybrane problemy i instytucje prawa pracy a konstytucyjne prawa $i$ wolności człowieka, Warszawa 2013.

Społeczne ubezpieczenia wypadkowe i chorobowe. Komentarz, red. M. Gersdorf, B. Gudowska, Warszawa 2012.

Strusińska-Żukowska J., Odprawy pieniężne dla pracowników, „Prawo Pracy” 2000, nr 1.

Szubert W., Zarys prawa pracy, Warszawa 1972.

Ślebzak K., Prawny charakter sktadek na ubezpieczenie społeczne, [w:] Ubezpieczenie społeczne - dawniej i dziś. W 80-lecie uchwalenia ustawy o ubezpieczeniu społecznym, Wrocław 2013.

Ślebzak K., Prawo do zabezpieczenia społecznego w Konstytucji RP. Zagadnienia podstawowe, Warszawa 2016.

Przegląd Prawa i Administracji CXX, 2020, cz. 1 i 2

(C) for this edition by CNS 
Świątkowski A., Kodeks pracy. Komentarz, Warszawa 2016.

Świątkowski A., Wujczyk M., Bezpieczeństwo prawne i socjalne jako uniwersalna aksjologiczna podstawa wspótczesnego prawa pracy i zabezpieczenia społecznego. Wybrane zagadnienia, [w:] Aksjologiczne podstawy prawa pracy i ubezpieczeń spolecznych, red. M. Skąpski, K. Ślebzak, Poznań 2014.

Ustawa o systemie ubezpieczeń społecznych. Komentarz, red. J. Wantoch-Rekowski, LEX 2015.

Wagner B., Wprowadzenie, [w:] Ubezpieczenia chorobowe, red. B. Wagner, A. Malaka, Iwonicz-Zdrój 2010.

Wagner B., Zasiłki i wynagrodzenie za czas nieobecności w pracy, PUSiG 2000, nr 5.

Wyka T., [w:] Kodeks pracy. Komentarz, red. K.W. Baran, Warszawa 2018.

Zieleniecki M., Rola zasiłku wyrównawczego $i$ renty szkoleniowej $w$ rehabilitacji zawodowej, [w:] Ryzyko niezdolności do pracy w zabezpieczeniu społecznym, red. U. Jackowiak, R. Ziółkowska, Gdańsk 2006. 